\title{
AUDITOR DAN TINGKAT MATERIALITAS
}

\author{
Hilda Rizki Aulia \\ Sigit Handoyo \\ Universitas Islam Indonesia \\ sihando@yahoo.com
}

\begin{abstract}
One of the phases of audit to auditor is determining the level of materiality. It is very important and must be done by auditors since the level of materiality has tight relationship both the level of risk and the obtaining of evidence. There are some factors may influence in determining of the materiality level. This research will test the influence of professionalism, experiences and the knowledge of auditor to detech fraud in determining of materiality level. Auditors work at accounting firm in Yogyakarta and Solo are the subjects and respondents of this research. Hypothesis testing is using multiple regression with SPSS for windows version 16.0 as a tool. The result proves that the determining of materiality level by auditor is significantly influenced by professionalism, experiences and the knowledge of auditor to detect fraud.
\end{abstract}

Keyword: materiality level, professionalism, experiences, knowledge to detect fraud.

\begin{tabular}{l}
\hline PENDAHULUAN \\
Pemeriksaan atas laporan keuangan \\
oleh auditor yang merupakan pihak yang \\
independen sangat diperlukan oleh pihak-pihak \\
eksternal. Tugas utama seorang auditor adalah \\
melaksanakan audit dan memberikan opininya \\
atas suatu laporan keuangan perusahaan yang \\
berpedoman pada standar profesional yang ada \\
berdasarkan pada pendidikan, pengalaman, \\
pelatihan yang dimilikinya, serta dengan sikap \\
profesional, kompeten, obyektif, dan tidak \\
memihak. \\
Seorang auditor dituntut untuk dapat \\
memberikan hasil laporan auditan yang dapat \\
dipercaya dan sesuai dengan fakta yang ada. \\
Hal ini karena auditor tidak bekerja untuk \\
kepentingan kliennya, melainkan untuk pihak \\
lain yang berkepentingan terhadap laporan \\
keuangan auditan. Salah satu tanggung jawab \\
auditor adalah menetapkan apakah suatu
\end{tabular}

laporan keuangan mengandung salah saji dalam jumlah yang material sehingga apabila auditor menemukan salah saji yang bersifat material maka ia harus mengkomunikasikan hal tersebut kepada klien sehingga penyesuaian dapat dilakukan berdasarkan bukti-bukti yang ada. Jika klien menolak untuk melakukan perbaikan atas laporan keuangan, pendapat dengan kualifikasi atau pendapat tidak wajar akan dikeluarkan oleh auditor, tergantung pada sejauh mana tingkat kesalahan yang bersifat material terjadi. Tanggung jawab inilah yang menuntut auditor harus bisa memeriksa dengan teliti laporan keuangan kliennya, tentunya berdasarkan prinsip akuntansi berterima umum (Basri, 2011).

Karena pendapat auditor akan dimanfaatkan oleh publik maka auditor harus bersikap sangat berhati-hati oleh karena itu auditor harus melaksanakan semua tahap audit sesuai dengan standar audit yang yang ditetapkan oleh organisasi profesi. Kesalahan dalam memberikan 
penyataan atau pendapat dapat diminimalisir yang salah satunya dengan ketepatan auditor dalam mempertimbangkan tingkat materialitas. Penetapan tingkat materialitas merupakan salah satu dasar penerapan dari standar audit, terutama standar pekerjaan lapangan dan standar pelaporan (Sulistia, 2013).

Materialitas sendiri merupakan besarnya nilai yang dihilangkan atau salah saji informasi akuntansi, yang dilihat dari keadaan yang melingkupinya, dapat mengakibatkan perubahan atas atau pengaruh terhadap pertimbangan orang yang meletakkan kepercayaan terhadap informasi tersebut, karena adanya penghilangan atau salah saji (Mulyadi, 2002). Pertimbangan tingkat materialitas sangat penting dilakukan oleh Akuntan Publik, hal ini disebabkan karena pertimbangan tingkat materialitas dapat mempengaruhi dalam penentuan jumlah bukti yang harus dikumpulkan atau kecukupan bukti, bagaimana bukti itu akan diperoleh, dan kriteria yang digunakan untuk mengevaluasi bukti tersebut (Suraida, 2005). Sehingga dapat disimpulkan bahwa tujuan dari penetapan tingkat materialitas adalah untuk membantu auditor merencanakan pengumpulan bukti yang cukup. Meskipun tidak semua informasi keuangan diperlukan atau seharusnya dikomunikasikan dalam laporan keuangan akuntansi, hanya informasi yang bersifat material yang seharusnya disajikan. Disamping itu penetapan tingkat materialitas dalam proses audit oleh auditor atas suatu entitas tidak akan sama dengan entitas lain tergantung pada ukuran entitas tersebut.

Pertimbangan atas materialitas ini bukanlah hal yang mudah untuk dilakukan karena standar audit tidak mengatur secara rinci tentang nilai materialitas yang harus ditentukan auditor. Oleh karena itu baik tidaknya pertimbangan auditor tentang materialitas ditentukan oleh kualitas auditor itu sendiri yang dipengaruhi oleh beberapa faktor, diantaranya adalah profesionalisme auditor, pengalaman, serta pengetahuan akuntan publik dalam mendeteksi kekeliruan.

Dengan demikian, pendapat dari seorang akuntan publik secara tidak langsung tergantung pada pertimbangan tingkat materialitas yang ditetapkan oleh akuntan publik terhadap laporan keuangan perusahaan tersebut. Apabila seorang akuntan publik keliru dalam mempertimbangkan tingkat materialitas, maka akan menghasilkan keputusan yang salah dan dapat merugikan pihak pengguna informasi laporan keuangan.

Dari uraian latar belakang masalah di atas maka rumusan masalah dari penelitian ini adalah sebagai berikut: (1) Apakah profesionalisme memiliki pengaruh positif terhadap pertimbangan dalam penentuan tingkat materialitas?, (2) Apakah pengalaman memiliki pengaruh positif terhadap pertimbangan dalam penentuan tingkat materialitas?, (3) Apakah pengetahuan akuntan publik dalam mendeteksi kekeliruan mempunyai pengaruh positif terhadap pertimbangan dalam penentuan tingkat materialitas?.

\section{REVIEW LITERATUR DAN HIPOTESIS}

\section{Profesionalisme}

Dalam kaitanya denga audit, secara umum profesionalisme dapat diartikan sebagai sikap wajib yang harus dimiliki oleh auditor untuk melaksanakan tugas-tugasnya dengan kecermatan dan kesungguhan yang dimiliki. Profesi dan profesionalisme dapat dibedakan secara konseptual seperti yang dikemukakan oleh Lekatompessy (Herawaty dan Susanto, 2009:15). Profesi merupakan jenis pekerjaan yang memenuhi beberapa kriteria, sedangkan profesionalisme merupakan suatu atribut individual yang penting tanpa melihat apakah suatu pekerjaan merupakan suatu profesi atau tidak. Sebagai profesional, akuntan publik dituntut untuk memenuhi tanggung jawabnya terhadap masyarakat, terhadap klien dan terhadap rekan seprofesi termasuk untuk berperilaku yang 
terhormat, sekalipun itu merupakan pengorbanan pribadi.

Konsep profesionalisme moderen dalam melakukan suatu pekerjaan seperti dikemukakan oleh Lekatompessy (Herawaty dan Susanto, 2009:15), berkaitan dengan dua aspek penting, yaitu aspek struktural dan aspek sikap. Aspek struktural karakteristiknya merupakan bagian dari pembentukan tempat pelatihan, pembentukan asosiasi profesional dan pembentukan kode etik. Sedangkan aspek sikap berkaitan dengan pembentukan jiwa profesionalisme. Wahyudi dan Mardiyah (2006) menyatakan bahwa profesionalisme merupakan hal penting dan menjadi syarat utama bagi seseorang yang bekerja sebagai auditor.

\section{Pengalaman}

Pengalaman merupakan suatu proses pembelajaran dan pertambahan perkembangan potensi bertingkah laku baik dari pendidikan formal maupun non formal atau bisa diartikan sebagai suatu proses yang membawa seseorang kepada suatu pola tingkah laku yang lebih tinggi. Suatu pembelajaran juga mencakup perubahan yang relatif tepat dari perilaku yang diakibatkan pengalaman, pemahaman dan praktik (Asih, 2006:12).

Pengalaman merupakan atribut yang penting bagi auditor, yang dapat terbukti dengan tingkat kesalahan yang dibuat auditor. Auditor yang sudah berpengalaman biasanya lebih dapat mengingat kesalahan atau kekeliruan yang tidak lazim atau wajar dan lebih selektif terhadap informasi-informasi yang relevan dibandingkan dengan auditor yang kurang berpengalaman (Asih, 2006:13). Sebagaimana yang disebutkan dalam Standar Profesional Akuntan Publik (SPAP, 2011) bahwa persyaratan yang dituntut dari seorang auditor independen adalah orang yang memiliki pendidikan dan pengalaman yang memadai yang biasanya diperoleh dari praktikpraktik dalam bidang auditing sebagai auditor independen.

\section{Pengetahuan Mendeteksi Kekeliruan}

Herawaty dan Susanto (2009:16) mengungkapkan bahwa pengetahuan mendeteksi kecurangan merupakan perolehan informasi yang memadai tentang pendeteksian kecurangan yang didapat dari berbagai pelatihan formal dan pengalaman khusus yang dapat membuat auditor menjadi lebih ahli dalam mendeteksi kecurangan.

Seorang auditor dinyatakan memiliki pengetahuan dalam mendeteksi kekeliruan ketika auditor tersebut melakukan pertimbangan penting untuk mengungkap kekeliruan dengan mengidentifikasi faktor-faktor yang meningkatkan risiko adanya kekeliruan. Banyak cara yang dilakukan oleh akuntan publik dalam memperoleh pengetahuan mendeteksi kekeliruan diantaranya bisa diperoleh dari berbagai pelatihan formal maupun dari pengalaman khusus, berupa kegiatan seminar, lokakarya serta pengarahan dari auditor senior kepada auditor juniornya (Herawati dan Susanto, 2009). Pengetahuan juga dapat diperoleh dari frekuensi seorang akuntan publik melakukan pekerjaan dalam proses audit laporan keuangan. Seseorang yang melakukan pekerjaan sesuai dengan pengetahuan yang dimilikinya akan memberikan hasil yang lebih baik daripada mereka yang tidak memiliki pengetahuan yang cukup memadai akan tugasnya. Menurut Mardisar dan Sari (2007), perbedaan pengetahuan di antara auditor akan berpengaruh terhadap cara auditor menyelesaikan sebuah pekerjaan.

Pengetahuan akuntan publik digunakan sebagai salah satu kunci dalam keefektifan kerja. Dalam pengauditan, pengetahuan tentang bagaimana bermacam-macam pola yang berhubungan dengan kemungkinan kekeliruan dalam laporan keuangan adalah penting untuk perencanaan secara efektif Noviyani (2009).

\section{Materialitas}

Definisi dari pengertian materialitas menurut Boynton (2006) adalah besarnya nilai yang dihilangkan atau salah saji informasi akuntansi, 
dilihat dari keadaan yang melingkupinya, yang mungkin dapat mengakibatkan perubahan pengaruh terhadap pertimbangan orang yang meletakan kepercayaan atas informasi tersebut karena adanya penghilangan atau salah saji tersebut. Berdasarkan definisi-definisi diatas dapat disimpulkan bahwa materialitas adalah suatu salah saji informasi dalam laporan keuangan dapat dianggap material jika besaranya atas salah saji tersebut dapat mempengaruhi keputusan pemakai laporan keuangan. Dari definisi tersebut juga mengharuskan auditor untuk mempertimbangkan baik keadaan yang berkaitan dengan entitas maupun kebutuhan informasi pihak yang meletakan kepercayaan atas laporan keuangan tersebut.

Konsep materialitas menunjukkan seberapa besar salah saji yang dapat diterima oleh seorang auditor agar para pemakai laporan keuangan tidak terpengaruh oleh salah saji tersebut. Dua alasan mengapa konsep materialitas penting dalam audit, yaitu: pertama, agar pemakai informasi akuntansi dalam membaca laporan keuangan dapat dengan mudah, maka pengungkapan data penting harus dipisahkan dari data yang kurang penting, karena pengungkapan data penting yang bersamaan dengan data tidak penting cenderung menyesatkan pemakai laporan keuangan. Kedua, proses pemeriksaan akuntansi dimaksudkan untuk mendapatkan tingkat jaminan (guarantee) yang layak mengenai kewajaran penyajian laporan keuangan pada suatu waktu tertentu ( Fridati, 2005:15). Peran konsep materialitas adalah untuk mempengaruhi kualitas dan kuantitas informasi akuntansi yang diperlukan oleh auditor dalam membuat keputusan yang berkaitan dengan bukti.

Pertimbangan yang digunakan oleh auditor dalam menentukan apakah suatu informasi termasuk ke dalam jenis informasi yang kurang hingga sangat material meliputi: besar dan sifat informasi, ketidakpastian yang melekat dalam informasi, seberapa jauh dampak informasi tersebut meresap, dan kemungkinan kesalahan yang diakibatkan oleh informasi tersebut.

Dengan demikian pertimbangan tingkat materialitas adalah pertimbangan auditor atas besarnya penghilangan atau salah saji informasi akuntansi yang dapat mempengaruhi pertimbangan pihak yang meletakkan kepercayaan terhadap informasi tersebut yang dilihat berdasarkan seberapa penting tingkat materialitas, pengetahuan tentang tingkat materialitas, risiko audit, tingkat materialitas antar perusahaan dan urutan tingkat materialitas dalam rencana audit.

\section{Pengaruh Profesionalisme Auditor terhadap Pertimbangan Tingkat Materialitas}

Bagi auditor profesional, adalah kewajibannya untuk membuat perencanaan sebelum melakukan proses pengauditan laporan keuangan, termasuk penentuan tingkat materialitas. Seorang akuntan publik yang profesional akan mempertimbangkan material atau tidaknya informasi dengan tepat, karena hal ini berhubungan dengan jenis pendapat yang akan diberikan. Dengan demikian, semakin tinggi pengabdian profesi seorang auditor, maka sanagt memungkinkan bahwa dalam pertimbangan tingkat materialitas dalam laporan keuangan akan semakin tepat. Profesionalisme auditor tersebut dapat diukur melalui pengabdian auditor terhadap profesi, kesadaran auditor akan kewajiban sosial, kemandirian, keyakinan terhadap peraturan profesi dan hubungan dengan sesama profesi.

Penelitian yang dilakukan Febrianty (2012) menunjukkan bahwa profesionalisme auditor berpengaruh positif terhadap pertimbangan tingkat materialitas dalam proses audit laporan keuangan. Semakin tinggi tingkat profesionalisme akuntan publik semakin baik pula auditor dalam melakukan pertimbangan dalam penentuan tingkat materialitas dalam melaksanakan audit laporan keuangan. Penelitian lainnya yang dilakukan oleh Sinaga dan Isgyarta (2012) juga menunjukkan bahwa 
profesionalisme auditor berpengaruh positif terhadap pertimbangan tingkat materialitas.

Dengan demikian maka hipotesis yang diajukan adalah sebagai berikut:

$H_{1}$ : Profesionalisme auditor berpengaruh positif terhadap pertimbangan dalam penentuan tingkat materialitas.

\section{Pengaruh Pengalaman terhadap Pertim- bangan Tingkat Materialitas.}

Auditor yang memiliki pengalaman yang berbeda, akan berbeda pula dalam memandang dan menanggapi informasi yang diperoleh selama melakukan pemeriksaan dan juga dalam memberi kesimpulan audit terhadap obyek yang diperiksa berupa pemberian pendapat. Semakin banyak pengalaman seorang auditor, maka dalam melakukan pertimbangan dalam menentukan tingkat materialitas audit atas laporan keuangan perusahaan akan semakin baik. Penelitian yang dilakukan oleh Kusuma (2012) menunjukkan bahwa pengalaman berpengaruh positif terhadap pertimbangan tingkat materialitas dalam proses audit laporan keuangan. Hal ini konsisten dengan hasil penelitian yang dilakukan oleh Prabowo (2012) yang menunjukkan bahwa pengalaman berpengaruh positif terhadap pertimbangan tingkat materialitas.

Dengan demikian maka hipotesisi yang diajukan adalah sebagai berikut:

$\mathrm{H}_{2}$ : Pengalaman auditor memiliki pengaruh positif terhadap pertimbangan dalam penentuan tingkat materialitas.

\section{Pengaruh Pengetahuan Mendeteksi Keke- liruan terhadap Pertimbangan Tingkat Materialitas.}

Pengetahuan akuntan publik tentang pendeteksian kekeliruan semakin berkembang seiring dengan tingkat pengalaman kerja. Semakin tinggi pengetahuan akuntan publik dalam mendeteksi kekeliruan maka semakin baik pula dalam mempertimbangan tingkat materialitas khususnya dalam melakukan tugas yang berhubungan dengan pengungkapan kekeliruan. Penelitian yang dilakukan Herawaty dan Susanto (2009) menunjukkan bahwa pengetahuan mendeteksi kekeliruan berpengaruh positif terhadap pertimbangan tingkat materialitas dalam proses audit atas laporan keuangan. Hasil yang sama diperoleh dari hasil penelitian yang dilakukan oleh Lestari dan Utama (2013) yang menunjukkan bahwa pengetahuan auditor dalam mendeteksi kekeliruan berpengaruh positif terhadap pertimbangan tingkat materialitas. Semakin tinggi pengetahuan dalam mendeteksi kekeliruan semakin baik pula pertimbangan dalam penentuan tingkat materialitas.

Dengan demikian maka hipotesisi yang diajukan adalah sebagai berikut:

$\mathrm{H}_{3}$ : Pengetahuan mendeteksi kekeliruan akuntan publik memiliki pengaruh positif terhadap pertimbangan dalam penentuan tingkat materialitas.

\section{Kerangka Pemikiran}

Gambar berikut merupakan kerangka pemikiran atas penelitian ini. Kerangka pemikiran penelitian ini menggambarkan variabel profesionalisme, pengalaman dan pengetahuan akuntan publik dalam mendeteksi kekeliruan sebagai variabel dependen sedangkan pertimbangan tingkat materialitas sebagai variabel independen.

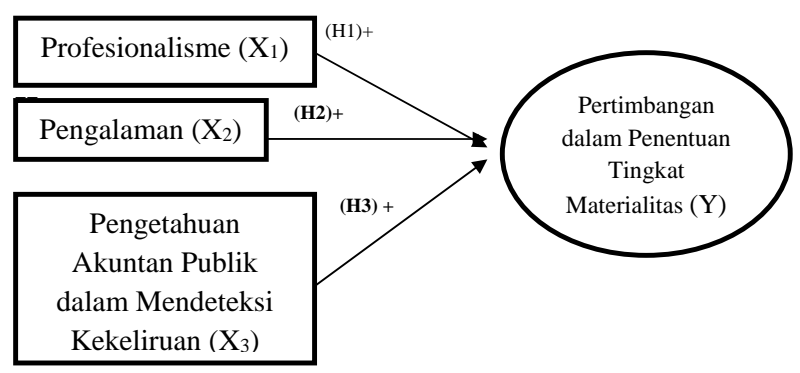

\section{METODE PENELITIAN}

\section{Jenis dan Sumber Data}

Data yang digunakan dalam penelitian ini adalah data primer yang merupakan data 
langsung dan segera dapat diperoleh dari sumbernya, diamati, dan dicatat pertama kalinya. Dalam penelitian ini data primer yang digunakan bersumber dari responden yang merupakan auditor independen yang bekerja di Kantor Akuntan Publik (KAP) di Yogyakarta dan Solo. Data primer ini dikumpulkan dengan menggunakan kuesioner (daftar pertanyaan) melalui survey langsung kepada responden.

\section{Metode Analisis Data}

Alat statistik yang digunakan untuk menguji hipotesis yaitu dengan menggunakan regresi berganda dengan bantuan perangkat lunak SPSS for windows versi 16.0. Model persamaannya dapat di gambarkan sebagai berikut :

$\mathrm{Y}=\alpha+\beta_{1} \mathrm{X}_{1}+\beta_{2} \mathrm{X}_{2}+\beta_{3} \mathrm{X}_{3+} \varepsilon$

Keterangan :

$\mathrm{Y}=$ Persepsi atas materialitas

$\alpha=$ Konstanta

$\mathrm{X}_{1}=$ Profesionalisme

$\mathrm{X}_{2}=$ Pengalaman

$\mathrm{X}_{3}=$ Pengetahuan akuntan publik dalam mendeteksi kekeliruan

$\varepsilon \quad=$ Error

\section{HASIL PENELITIAN DAN PEMBAHASAN}

\section{Uji Validitas}

Uji validitas menggambarkan bagaimana kuesioner (pertanyaan atau item) sungguhsungguh mampu mengukur apa yang ingin diukur berdasarkan teori-teori dan ahli. Dengan kata lain, semakin tinggi validitas suatu test maka alat test tersebut semakin tepat mengenai sasarannya (Sekaran, 2003). Untuk menguji validitas konstruk suatu alat test bisa menggunakan metode korelasi yaitu korelasi alat tes yang diajukan dengan membangunnya. Pada penerapaannya, uji validitas dalam penelitian ini dilakukan dengan bantuan perangkat lunak SPSS dengan menggunakan korelasi pearson antara tiap variabel pertanyaan terhadap rata-rata dari tiap konstruk pertanyaan tersebut. Kriteria yang digunakan adalah apabila nilai koefisien korelasi $>\mathrm{r}$ tabel maka dapat dinyatakan item tersebut valid sehingga seluruh pertanyaan dalam kuesioner dinyatakan valid .

\section{Uji Reliabilitas}

Reliabilitas (keandalan) merupakan ukuran suatu kestabilan dan konsistensi responden dalam menjawab hal yang berkaitan dengan konstruk-konstruk pertanyaan yang merupakan dimensi suatu variabel dan disusun dalam suatu bentuk kuesioner. Uji Reliabilitas ditujukan untuk mengetahui stabilitas dan konsistensi di dalam pengukuran (Sekaran, 2003). Uji reliabilitas dapat dilakukan dengan Cronbach Alpha Suatu instrumen penelitian dinyatakan reliabel apabila nilai $r_{\text {alpha }}>0,60$.

\section{Hasil Pengumpulan Data}

Peneliti telah menyebar kuesioner ke 5 Kantor Akuntan Publik di wilayah Yogyakarta sebanyak 35 eksemplar dan menyebar kuesioner ke 2 Kantor Akuntan Publik di wilayah Solo sebanyak 20 eksemplar dan total kuesioner yang kembali sebanyak 47 eksemplar. Dari kuesioner yang kembali tersebut, terdapat 8 kuesioner yang tidak dapat dijadikan data penelitian, karena tidak diisi lengkap oleh responden. Total kuesioner yang dapat dijadikan sumber data sebanyak 47 kuesioner. Hasil selengkapnya dapat dilihat pada tabel berikut ini.

\section{Tabel 1}

Hasil Pengumpulan Kuesioner

\begin{tabular}{|l|c|c|}
\hline \multicolumn{1}{|c|}{ Ketarangan } & Jumlah & \% \\
\hline Kuesioner yang disebar & 55 & 100 \\
Kuesioner yang tidak diisi lengkap & 8 & 14,5 \\
Kuesioner yang dapat diolah kembali & 47 & 85,5 \\
\hline
\end{tabular}

Sumber: Data primer diolah, 2014.

Karakteristik responden yang menjadi sampel dalam penelitian ini dibagi menjadi beberapa kelompok yaitu menurut, usia, jabatan, lama masa kerja dalam KAP. Berikut ini disajikan 
karakteristik responden menurut usia, jabatan dan masa kerja.

\section{Analisis Deskriptif}

Analisis dalam penelitian ini menggambarkan analisis deskriptif atas jawaban yang diberikan untuk kemudian disajikan dalam bentuk tabel. Analisa deskriptive digambarkan untuk menguraikan tentang karakteristik dari suatu keadaan dari obyek yang diteliti. Responden yang diambil untuk penelitian ini sebanyak 47 orang, yaitu auditor yang ada di Daerah Istimewa Yogyakarta dan Solo.

\section{Karakteristik Responden}

Karakteristik responden yang dianalisis dalam penelitian ini meliputi, usia, jabatan dan lama masa kerja.

Usia

Berdasarkan usia, maka responden dalam penelitian ini diklasifikasikan sebagai berikut:

\section{Tabel 2}

\section{Kasifikasi Responden Berdasarkan Usia}

\begin{tabular}{|c|c|c|}
\hline Usia & $\begin{array}{c}\text { Jumlah } \\
\text { (orang) }\end{array}$ & $\begin{array}{c}\text { Persentase } \\
\text { (\%) }\end{array}$ \\
\hline Kurang dari 30 tahun & 35 & 72,3 \\
30-35 tahun & 5 & 10,6 \\
35-40 tahun & 3 & 6,4 \\
40-45 tahun & 4 & 8,5 \\
Lebih dari 45 tahun & 1 & 2,1 \\
\hline Total & 47 & $100 \%$ \\
\hline
\end{tabular}

Sumber : Data Primer Diolah, 2014.

Tabel 2 menunjukkan bahwa responden dalam penelitian ini sebagian besar berusia kurang dari 30 tahun yaitu sebanyak 35 orang $(72,3 \%)$, dilanjutkan dengan usia 30-35 tahun sebanyak 5 orang $(10,6 \%)$, berusia $40-45$ tahun sebanyak 4 orang $(8,5 \%)$, berusia $35-40$ tahun sebanyak 3 orang $(6,4 \%)$ dan yang berusia lebih dari 45 tahun ada 1 orang $(2,1 \%)$.

\section{Jabatan}

Berdasarkan jabatan, maka responden dalam penelitian ini dapat diklasifikasikan sebagai berikut:
Tabel 3

Klasifikasi Responden Berdasarkan Jabatan

\begin{tabular}{|c|c|c|}
\hline Jabatap & Frekuensi & $\%$ \\
\hline Karyawan Magang & 2 & 4,3 \\
Auditor Junior & 31 & 66,0 \\
Auditor Senior & 12 & 25,5 \\
Supervisor & 1 & 2,1 \\
Manager & 0 & 0 \\
Partner & 1 & 2,1 \\
\hline Total & 47 & $100 \%$ \\
\hline
\end{tabular}

Sumber: Data primer diolah, 2014.

Tabel 3 menunjukkan bahwa responden dalam penelitian ini sebagian besar auditor junior yaitu sebanyak 31 orang $(66,0 \%)$, auditor senior sebanyak 12 orang $(25,5 \%)$, auditor supervisor dan auditor partner masing-masing sebanyak 1 orang $(2,1 \%)$ dan magang sebanyak 0 orang $(0 \%)$.

\section{Lama kerja}

Berdasarkan lama kerja, maka responden dalam penelitian ini diklasifikasikan sebagai berikut:

\section{Tabel 4}

Karakteristik Responden Berdasarkan Lama Bekerja

\begin{tabular}{|c|c|c|}
\hline LamaBekerja & Frekuensi & $\%$ \\
\hline Kurang dari 1 tahun & 11 & 23,4 \\
$1-3$ tahun & 19 & 40,4 \\
3-5 tahun & 12 & 25,5 \\
Lebih dari 5 tahun & 5 & 10,6 \\
\hline Total & 47 & $100 \%$ \\
\hline
\end{tabular}

Sumber: Data primer diolah, 2014.

Tabel 3 menunjukkan bahwa responden dalam penelitian ini sebagian besar memiliki lama bekerja 1-3 tahun sebanyak 19 orang $(40,4 \%)$, dilanjutkan dengan yang memiliki lama bekerja 3-5 tahun sebanyak 12 orang (25,5\%), dilanjutkan dengan yang memiliki lama bekerja kurang dari 1 tahun sebanyak 11 orang $(23,4 \%)$ dan yang memiliki lama bekerja lebih dari 5 tahun sebanyak 5 orang $(10,6 \%)$.

\section{Hasil Uji Validitas dan Reliabilitas Instrumen}

Untuk menguji kuesioner sebagai instrumen penelitian digunakan uji validitas dan uji reliabilitas. Uji validitas digunakan untuk 
mengetahui item-itemyang ada di dalam kuesioner mampu mengukur peubah yang didapatkan dalam penelitian ini. Apabila nilai koefisien korelasi $>r$ tabel , maka dapat dinyatakan item tersebut valid, sehingga seluruh pertanyaan dalam kuesioner dinyatakan valid. Selanjutnya kuesioner tersebut akan digunakan dalam penelitian. Dengan jumlah responden sebanyak 47 auditor maka dapat diketahui nilai $\mathrm{r}$ tabel pada level signifikan 5\% adalah sebesar 0,2876.

Untuk pengujian reliabilitas dilakukan dengan teknik cronbach alpha, dengan jumlah sampel uji kuesioner sebanyak 47 responden. Suatu instrumen penelitian dinyatakan reliable apabila nilai $r_{\text {alpha }}>0,60$. Perhitungan reliabilitas alat ukur penelitian ini dilakukan dengan bantuan program program SPSS for Windows Release 16.00. Berikut ini hasil pengujian validitas dan reliabilitas instrumen penelitian :

Tabel 5

\section{Hasil Uji Validitas dan Reliabilitas Item-item Variabel Penelitian}

\begin{tabular}{|c|c|c|c|c|}
\hline Variabel & Item & r hitung & r tabel & Keterangan \\
\hline \multirow[t]{15}{*}{ Profesionalisme } & Prof 1 & 0.658 & 0.2876 & Valid \\
\hline & Prof 2 & 0.401 & 0.2876 & Valid \\
\hline & Prof 3 & 0.373 & 0.2876 & Valid \\
\hline & Prof 4 & 0.602 & 0.2876 & Valid \\
\hline & Prof 5 & 0.453 & 0.2876 & Valid \\
\hline & Prof 6 & 0.576 & 0.2876 & Valid \\
\hline & Prof 7 & 0.411 & 0.2876 & Valid \\
\hline & Prof 8 & 0.647 & 0.2876 & Valid \\
\hline & Prof 9 & 0.438 & 0.2876 & Valid \\
\hline & Prof 10 & 0.502 & 0.2876 & Valid \\
\hline & Prof 11 & 0.463 & 0.2876 & Valid \\
\hline & Prof 12 & 0.396 & 0.2876 & Valid \\
\hline & Prof 13 & 0.685 & 0.2876 & Valid \\
\hline & Prof 14 & 0.484 & 0.2876 & Valid \\
\hline & Prof 15 & 0.355 & 0.2876 & Valid \\
\hline \multirow[t]{3}{*}{ Pengalaman } & Pnglmn & 0.745 & 0.2876 & Valid \\
\hline & Pnglmn & 0.804 & 0.2876 & Valid \\
\hline & $\begin{array}{l}\text { Pnglmn } \\
2\end{array}$ & 0.792 & 0.2876 & Valid \\
\hline
\end{tabular}

\begin{tabular}{|l|l|l|l|l|}
\hline Variabel & Item & r hitung & r tabel & Keterangan \\
\hline Pengetahuan & PMK 1 & 0.375 & 0.2876 & Valid \\
\hline & PMK 2 & 0.497 & 0.2876 & Valid \\
\hline & PMK 3 & 0.530 & 0.2876 & Valid \\
\hline & PMK 4 & 0.396 & 0.2876 & Valid \\
\hline & PMK 5 & 0.658 & 0.2876 & Valid \\
\hline Materialitas & PMK 6 & 0.503 & 0.2876 & Valid \\
\hline & M 1 & 0.491 & 0.2876 & Valid \\
\hline & M 2 & 0.332 & 0.2876 & Valid \\
\hline & M 3 & 0.328 & 0.2876 & Valid \\
\hline & M 4 & 0.512 & 0.2876 & Valid \\
\hline & M 5 & 0.416 & 0.2876 & Valid \\
\hline & M 6 & 0.441 & 0.2876 & Valid \\
\hline & M 7 & 0.754 & 0.2876 & Valid \\
\hline & M 8 & 0.457 & 0.2876 & Valid \\
\hline & M 9 & 0.603 & 0.2876 & Valid \\
\hline & M 10 & 0.684 & 0.2867 & Valid \\
\hline & M 11 & 0.454 & 0.2867 & Valid \\
\hline & M 12 & 0.813 & 0.2867 & Valid \\
\hline M 13 & 0.584 & 0.2867 & Valid \\
\hline & Primer Diolah 2014 & & \\
\hline & &
\end{tabular}

Sumber : Data Primer Diolah, 2014.

Dari Tabel 5 tersebut di atas dapat diketahui bahwa seluruh butir pertanyaan dinyatakan valid karena memiliki koefisien korelasi $\mathrm{r}$ hitung $>$ 0,2876 .

Selanjutnya dari butir-butir yang valid dilakukan uji reliabilitas, yang hasilnya dapat ditampilkan seperti pada Tabel 6 .

\section{Tabel 6}

\section{Hasil Uji Reliabilitas}

\begin{tabular}{|l|c|c|c|}
\hline \multicolumn{1}{|c|}{ Varaibel } & $\begin{array}{c}\text { Koefisien } \\
\text { Alpha } \\
\text { Cronbach's }\end{array}$ & $\begin{array}{c}\text { Batasan } \\
\text { minimum }\end{array}$ & Keterangan \\
\hline Profesionalisme & 0.829 & 0.6 & Reliabel / Handal \\
\hline Pengalaman & 0.886 & 0.6 & Reliabel / Handal \\
\hline $\begin{array}{l}\text { Pengetahuan } \\
\text { Mendeteksi } \\
\text { Kekeliruan }\end{array}$ & 0.781 & 0.6 & Reliabel / Handal \\
\hline Materialitas & 0.750 & 0.6 & Reliabel / Handal \\
\hline
\end{tabular}

Sumber : Data Primer Diolah, 2014.

Dari Tabel 6 tersebut di atas dapat diketahui bahwa koefisien Cronbach's Alpha> 0,60 , sehingga seluruh pertanyaan dalam 
kuesioner pada item-item pertanyaan variabel profesionalisme, pengalaman dan pengetahuan mendeteksi kekeliruan dan tingkat materialitas dapat dinyatakan reliable atau handal.

\section{Hasil Autokorelasi dan Koefisien Determinasi $\left(\mathbf{R}^{2}\right)$}

\section{Tabel 7}

Model Summary ${ }^{b}$

\begin{tabular}{|l|r|r|r|r|r|}
\hline Model & \multicolumn{1}{|c|}{$\mathrm{R}$} & $\begin{array}{c}\mathrm{R} \\
\text { Square }\end{array}$ & $\begin{array}{c}\text { Adjusted } \\
\text { R Square }\end{array}$ & $\begin{array}{c}\text { Std. Error of } \\
\text { the Estimate }\end{array}$ & Durbin-Watson \\
\hline 1 & $.681^{\mathrm{a}}$ & .463 & .426 & .17040 & 1.973 \\
\hline
\end{tabular}

a. Predictors: (Constant), pengetahuan, pengalaman, profesionalisme

b. Dependent Variable: materialitas

Sumber : Data primer yang diolah, 2014

Dari tabel di atas dapat diketahui besarnya nilai Durbin Watson sebesar 1.973. Nilai D-W menurut tabel dengan $n=45$ dan jumlah variabel independen $3(\mathrm{k}-3)$ didapat angka dl=1.383 dan $\mathrm{du}=1.666$. Oleh karena itu nilai D-W 1.973 lebih besar dari batas ats (du) 1.666 dan kurang dari 4-1.666 (4-du), maka dapat disimpulkan bahwa tidak ada autokorelasi positif atau negatif atau dapat disimpulkan tidak terdapat autokorelasi.

Kemudian berdasarkan data di diatas diperoleh nilai koefisien determinasi atau adjusted $R$-square sebesar 0.426 atau $42.6 \%$. Hal ini berarti $57.4 \%$ pertimbangan tingkat materialitas dapat dijelaskan oleh variasi ketiga variabel independen yaitu profesionalisme auditor, pengalaman dan pengetahuan mendeteksi kekeliruan sedangkan sisanya $57.4 \%$ dijelaskan oleh faktor-faktor lain diluar model penelitian.

\section{Pembahasan Hasil Penelitian \\ Tabel 8 \\ Coefficients $^{\mathrm{a}}$}

\begin{tabular}{|c|c|c|c|c|c|c|}
\hline & \multicolumn{2}{|c|}{$\begin{array}{c}\text { Unstandardized } \\
\text { Coefficients }\end{array}$} & \multirow{2}{*}{$\begin{array}{c}\begin{array}{c}\text { Standardized } \\
\text { Coefficients }\end{array} \\
\text { Beta }\end{array}$} & \multirow{2}{*}{$\mathrm{t}$} & \multirow{2}{*}{ Sig. } \\
\hline & & B & $\begin{array}{l}\text { Std. } \\
\text { Error }\end{array}$ & & & \\
\hline \multirow[t]{4}{*}{1} & (Constant) & 2.009 & .520 & & 3.862 & .000 \\
\hline & Profesionalisme & .585 & .109 & .622 & 5.388 & .000 \\
\hline & Pengalaman & .115 & .038 & .345 & 3.008 & .004 \\
\hline & Pengetahuan & .351 & .138 & .289 & 2.543 & .015 \\
\hline
\end{tabular}

a. Dependent Variable: materialitas

Sumber: Data primer yang diolah 2014

\section{Pengujian Hipotesis Pertama}

Uji hipotesis ini untuk mengetahui apakah profesionalisme berpengaruh positif terhadap pertimbangan tingkat materialitas. Pengujian ini dilakukan dengan menggunakan tingkat signifikan sebesar $\alpha=5 \%$. Berdasarkan diatas diperoleh nilai signifikansi $t$ sebesar 0,000 . Dengan demikian nilai signifikansi $t$ lebih kecil dari nilai signifikansi yang digunakan yaitu sebesar 0,05 atau $(0,000<0,05)$, dan nilai koefisien regresi sebesar 0.585 . Nilai tersebut dapat membuktikan bahwa $\mathrm{Ho}_{1}$ ditolak dan $\mathrm{Ha}_{1}$ diterima, yang berarti ada pengaruh positif signifikan variabel profesionalisme terhadap pertimbangan tingkat materialitas. Dengan hasil ini, maka dapat dinyatakan bahwa hipotesis pertama yang menyatakan profesionalisme berpengaruh positif terhadap pertimbangan dalam penentuan tingkat materialitas terbukti.

\section{Pengujian Hipotesis Kedua}

Uji hipotesis ini untuk mengetahui apakah pengalaman berpengaruh positif terhadap pertimbangan tingkat materialitas. Pengujian ini dilakukan dengan menggunakan tingkat signifikan sebesar $\alpha=5 \%$. Berdasarkan Tabel diatas diperoleh nilai signifikansi $t$ sebesar 0,004 . Dengan demikian nilai signifikansi t lebih besar dari nilai signifikansi yang digunakan yaitu sebesar 0,05 atau $(0,004<0,05)$,dan nilai koefisien regresi sebesar 0.115 . Nilai tersebut dapat membuktikan bahwa $\mathrm{Ho}_{1}$ ditolak dan $\mathrm{Ha}_{1}$ diterima, yang berarti ada pengaruh positif signifikan variabel pengalaman terhadap pertimbangan tingkat materialitas. Dengan hasil ini, maka dapat dinyatakan bahwa hipotesis kedua yang menyatakan profesionalisme berpengaruh positif terhadap pertimbangan dalam penentuan tingkat materialitas terbukti.

\section{Pengujian Hipotesisi Ketiga}

Uji hipotesis ini untuk mengetahui apakah pengetahuan mendeteksi kekeliruan berpengaruh positif terhadap pertimbangan tingkat materialitas. 
Pengujian ini dilakukan dengan menggunakan tingkat signifikan sebesar $\alpha=5 \%$. Berdasarkan Tabel diatas diperoleh nilai signifikansi t sebesar 0,015 . Dengan demikian nilai signifikansi t lebih kecil dari nilai signifikansi yang digunakan yaitu sebesar 0,05 atau $(0,015<0,05)$, dan nilai koefisien regresi sebesar 0.351 . Nilai tersebut dapat membuktikan bahwa $\mathrm{Ho}_{1}$ ditolak dan Hal diterima, yang berarti adanya pengaruh positif signifikan variabel pengalaman terhadap pertimbangan tingkat materialitas. Dengan hasil ini, maka dapat dinyatakan bahwa hipotesis kedua yang menyatakan profesionalisme berpengaruh positif terhadap pertimbangan dalam penentuan tingkat materialitas terbukti.

\section{Pembahasan}

Berdasarkan hasil pengujian diatas, dinyatakan bahwa profesionalisme berpengaruh positif terhadap pertimbangan dalam penentuan tingkat materialitas. Hal ini dapat dikatakan bahwa semakin baik profesionalisme seorang auditor, maka semakin tepat pula auditor dalam menentukan tingkat materialitas dalam melakukan audit. Keprofesionalan dalam sebuah pekerjaan sangat penting. Hal ini dikarenakan profesionalitas berhubungan dengan kebutuhan akan kepercayaan publik terhadap kualitas jasa yang diberikan profesi. Begitu halnya dengan seorang auditor, penting untuk meyakinkan klien dan pemakai laporan keuangan akan kualitas auditnya dalam hal ini yang berhubungan dengan pertimbangan terhadap tingkat materialitas laporan keuangan. Jika pemakai jasa tidak memiliki keyakinan pada auditor dalam mempertimbangkan tingkat materialitas, maka kemampuan para profesional itu untuk memberikan jasa kepada klien dan masyarakat secara efektif akan berkurang.

Penelitian yang telah dilakukan Wahyudi dan Mardiyah (2006) menunjukkan bahwa profesionalisme berpengaruh terhadap tingkat pertimbangan materialitas sebagaimana penelitian hal serupa yang dilakukan oleh Hastuti dkk. (2003) menyatakan bahwa profesionalisme menjadi syarat utama bagi orang yang bekerja sebagai akuntan publik. Hasil penelitian ini juga mendukung hasil penelitian sebelumnya yang dilakukan oleh Reni Yendrawati (2008), Arleen Herawaty dan Yulius (2009), Sinaga dan Isgyarta (2012), dan Wahyudi dan Mardiyah (2006) yang memberikan bukti bahwa profesionalisme mempunyai hubungan positif terhadap pertimbangan dalam penentuan tingkat materialitas.

Kemudian berdasarkan hasil pengujian diatas, dinyatakan bahwa variabel pengalaman berpengaruh positif signifikan terhadap pertimbangan tingkat materialitas. Hal ini menunjukkan semakin banyak pengalaman seorang auditor, maka pertimbangan tingkat materialitas dalam melakukan audit oleh auditor akan semakin tepat. Selain itu, semakin tinggi tingkat pengalaman seorang auditor, semakin baik pula pandangan dan tanggapan tentang informasi yang terdapat dalam laporan keuangan karena auditor telah banyak melakukan tugasnya atau telah banyak memeriksa laporan keuangan dari berbagai jenis industri.

Hasil penelitian ini konsisten dengan hasil penelitian yang dilakukan Prabowo (2012) yang menunjukkan bahwa pengalaman berpengaruh positif terhadap pertimbangan dalam penentuan tingkat materialitas dalam proses audit laporan keuangan. Sama halnya dengan hasil penelitian yang dilakukan oleh Miranda dan Muid (2013) yang menunjukkan bahwa pengalaman berpengaruh positif terhadap pertimbangan dalam penentuan tingkat materialitas

Hasil dari pengujian dalam penelitian juga menunjukkan bahwa variabel pengetahuan mendeteksi kekeliruan akuntan publik berpengaruh positif terhadap pertimbangan tingkat materialitas. Sehingga semakin tingginya pengetahuan para auditor dalam mendeteksi kekeliruan maka tentunya semakin baik pula 
mempertimbangan penentuan tingkat materialita. Hal ini menjelaskan bahwa seseorang yang melakukan pekerjaan sesuai dengan pengetahuan yang dimilikinya akan memberikan hasil yang lebih baik daripada mereka yang tidak memiliki pengetahuan yang cukup memadai akan tugasnya, sehingga tingginya pengetahuan akuntan publik ini dapat digunakan sebagai salah satu kunci keefektifan kerja khususnya dalam sajian informasi akuntansi. Hasil penelitian ini konsisten dengan hasil penelitian Herawati dan Susanto (2009), yang memberikan bukti bahwa pengetahuan mendeteksi kekeliruan berpengaruh positif signifikan terhadap pertimbangan tingkat materialitas dalam proses audit laporan keuangan. Sama halnya dengan penelitian yang dilakukan oleh Kurniawan (2010), Miranda dan Muid (2013) serta Sari (2011) yang menunjukkan bahwa pengetahuan auditor dalam mendeteksi kekeliruan berpengaruh positif signifikan terhadap pertimbangan dalam penentuan tingkat materialitas.

\section{KESIMPULAN DAN SARAN}

Berdasarkan hasil penelitian yang telah dilakukan maka dapat diambil kesimpulan bahwa profesionalisme, pengalaman auditor, dan pengetahuan mendeteksi kekeliruan berpengaruh positif signifikan terhadap pertimbangan dalam penentuan tingkat materialitas. Jadi, baik profesionalisme, pengalaman auditor, dan pengetahuan mendeteksi kekeliruan merupakan faktor yang sangat mempengaruhi auditor dalam proses pertimbangan dalam penentuan tingkat materialitas.

Penelitian ini terbatas pada objek penelitian profesi auditor yang bekerja dalam Kantor Akuntan Publik (KAP) di Yogyakarta dan Solo saja sehingga dimungkinkan adanya perbedaan hasil pembahasan ataupun kesimpulan untuk objek penelitian yang berbeda pula. Disamping itu pengambilan data dilakukan dengan melakukan penyebaran kuesioner sehingga data yang digunakan adalah hanya dari hasil kuesioner bisa jadi sangat subyektif dan tidak ada wawancara atau interview langsung dengan auditor.

\section{Saran}

Penelitian ini memiliki beberapa saran untuk penelitian selanjutnya dimana diharapkan penelitian selanjutnya agar lebih memperhatikan waktu penelitian. Waktu penelitian diharapkan tidak dilakukan pada waktu sibuk auditor. Sehingga lebih banyak lagi responden yang dapat dikumpulkan. Selain itu penelitian yang sama sebaiknya menambahkan jumlah sampel dan memperluas lokasi pengambilan sampel tidak hanya di Yogyakarta dan Solo saja serta teknik pengambilan data dimodifikasikan dengan menambahkan metode wawancara atau terlibat tatap muka langsung dengan responden, sehingga data yang digali akan lebih konkrit dengan kondisi yang sebenarnya.

\section{DAFTAR PUSTAKA}

Asih, 2006, Pengaruh Pengalaman Terhadap Peningkatan Keahlian Auditor dalam Bidang Auditing. Skripsi S-1. Tidak Dipublikasikan

Basri,Hasan, 2011,Pengaruh Dimensi Profesionalisme Auditor terhadap Pertimbangan Tingkat Materialitas dalam Proses Pengauditan Laporan Keuangan, Skripsi, Universitas Hasanuddin.

Boynton, C. William and Raymond N. Johnson, 2006. Modern Auditing: Assurance Services and the Integrity of Financial Reporting, 8th Edition, Johnson, John Wiley and Sons

Febrianty, 2012, Pengaruh profesionalisme Auditor terhadap Pertimbangan Tingkat Materialitas Audit Atas Laporan Keuanga, Jurnal Ekonomi dan Informasi Akuntansi, Palembang. 
Fridati, Winda, 2005. Analisis Hubungan antara Profesionalisme Auditor dengan Pertimbangan Tingkat Materialitas dalam Proses Pengauditan Laporan Keuangan di Yogyakarta. Skripsi. Fakultas Ekonomi. Universitas Islam Indonesia. Yogyakarta

Hastuti, Theresia Dwi Stefani L. I., dan Clara S, 2003. Hubungan antara Profisionalisme Auditor dengan Materialitas dalam Proses Pengauditan Laporan Keuangan, SNA VI, Universitas Airlangga Surabaya Herawaty, Arleen dan Yulius Kurnia Susanto, 2009, Pengaruh Profesionalisme, Pengetahuan Mendeteksi Kekeliruan, dan Etika Profesi terhadap Pertimbangan Tingkat Materialitas Akuntan Publik, Jurnal Akuntansi dan Keuangan, Vol. 11, No. 1, Jakarta.

IAPI, 2011,Standar Profesional Akuntan Publik, Salemba Empat, Jakarta

Kurniawan, Melati. 2010. Pengaruh Profesionalisme, Pengetahuan Akuntan Publik dalam Mendeteksi Kekeliruan, Independensi Auditor terhadap Pertimbangan Tingkat Materialitas dalam Proses Audit Laporan Keuangan. Skripsi. Universitas Unika Soegijapranata.

Kusuma, Novanda Friska Bayu Aji, 2012, Pengaruh Profesionalisme Auditor, Etika Profesi dan Pengalaman Auditor terhadap Pertimbangan Tingkat Materialitas, Skripsi S-1, Fakultas Ekonomi Universitas Negri Yogyakarta, Yogyakarta.

Lestari, Ni Made Ayu dan Utama, I Made Karya, 2013, Pengaruh Profesionalisme, Pengetahuan dalam Mendeteksi Kekeliruan, Pengalaman, Etika Profesi pada Pertimbangan Tingkat Materialitas. Skripsi, Universitas Udayana.
Miranda, Reza dan Dul Muid. 2013. Analisis Pengaruh Profesionalisme, Pengetahuan Mendeteksi kekliruan, Pengalaman Kerja Auditor, dan Etika Profesi terhadap Pertimbangan Tingkat Materialitas Akuntan Publik. Skripsi. Universitas Diponegoro Semarang

Mulyadi. 2002. Auditing. Buku 1 Edisi Keenam, Salemba Empat, Jakarta.

Noviyani, P., dan Bandi. 2002. Pengaruh Pengalaman dan Penelitian terhadap Struktur Pengetahuan Auditor tentang Kekeliruan. Prosiding Simposium Nasional Akuntansi V. 481-488.

Prabowo, Adia Adi, 2012. Pengaruh Profesionalisme Auditor, Etika Profesi dan Pengalaman Auditor Terhadap Pertimbangan Tingkat Materialitas. Jurnal Kajian Pendidikan dan Akuntansi Indonesia. Edisi III. Vol I

Sari N, Mardisar D, 2007, Pengaruh Akuntabilitas dan Pengetahuan Terhadap Kualitas Hasil Kerja Auditor, Simposium Nasional Akuntansi 10, Universitas Hasanudin, Makassar.

Sari, Tika Noor, 2011, Pengaruh Profesionalisme, Pengetahuan Akuntan Publik Mendeteksi Kekeliruan dan Etika Profesi terhadap Pertimbangan Tingkat Materialitas (Studi Empiris pada Kantor Akuntan Publik di Daerah Istimewa Yogyakarta), Skripsi S-1, Universitas Islam Indonesia, Yogyakarta.

Sekaran, Uma, 2009, Metodologi Penelitian Untuk Bisnis, Salemba Empat, Jakarta.

Sinaga, Marfin dan Jaka Isgiyarta, 2012, Analisis Pengaruh Profesionalisme Terhadap Tingkat Materialitas dalam Proses Pengauditzn Laporan Keuangan (Studi Empiris pada Auditor Eksternal di Kota Semarang), Skripsi S-1, Universitas Diponegoro. Sukrisno, Agus. 1996. 
Sulistia, Nida Umun, 2013, Analisis Sistem Pengendalian Internal (SPI) Klien terhadap Pertimbangan Tingkat Materialitas Audit Laporan Keuangan, Accounting Analysis Journal, Semarang.

Suraida. 2005. Uji Model Etika, Kompetensi, Pengalaman Audit dan Resiko Audit Terhadap Skeptisisme Profesional Auditor. Jurnal Akuntansi. Th IX/02/ Mei.
Wahyudi H, Mardiyah, 2006, Pengaruh Profesionalisme Auditor dengan Pertimbangan Tingkat Materialitas dalam Proses Pengauditan Laporan Keuangan, Simposium NasionalAkuntansi 9, Padang.

Yendrawati, Reni, 2008, Analisis Hubungan antara Profesionalisme Auditor dengan Pertimbangan Tingkat Materialitas dalam Proses Pengauditan Laporan Keuangan. Jurnal Penelitian dan Pengabdian. 